6. Tear near the ora serrata invisible with direct ophthalmoscopy. Except for the folds of the retina, it appeared like a spot of chorioretinitis. Closure of the hole cured the detachment.

\title{
Professor Dr. JOSEF MELLER (Vienna)
}

It is pleasant to salute outstanding men, and readers will have noticed that several recent articles in the Journal were dedicated to the subject of this address. On behalf of his British colleagues. we thank Professor Meller for the example he has set, and in offer. ing him congratulations on his seventy-fifth birthday (October 22, 1949) we wish him pleasant days in retirement. His work and character will be remembered for many years. On the occasion of the seventieth birthday of Ernst Fuchs, Meller wrote about his predecessor: "His name shines forth in our science as that of his great teacher von Arlt." Meller in his turn has carried on the outstanding work of the Vienna School.

Since 1898 until his retirement in October, 1944, he worked at the Eye Clinic of Vienna, except for a three-year period (1915 to 1918 ), when he was " ordinary " professor of ophthalmology at the Imperial and Royal University of Innsbruck, to which he had been appointed by the Emperor Francis Joseph. In 1918 he was appointed "ordinary" professur of Ophthalmology at the Imperial and Royal University in Vienna, but by a letter from the German Reichminister for Science and Education, Berlin, dated May 10, 1944, he was relieved of the post of leader and teacher in the Vienna Eye Clinic " in the interest of later development at the high schools," and he retired from his position on October 1, 1944.

Unfortunately he seldom visited this country, although he had a good command of English, but he attended the 50th Annual Congress of the Ophthalmological Society of the United Kingdom at London in 1930 and became known to many of the participants who recollect his qualities of sincerity, modesty and geniality. He was also seen at the Oxford Congress a few times, and contributed to important discussions at the meetings of that body. Many will remember his delivery of the 1934 Doyne Memorial Lecture, which emphasised the continental view that iridocyclitis is often tuberculous in nature (as is now agreed in this country). He also reported that in some such cases tubercle bacilli may be recovered from the blood and from the eye, and argued that sympathetic ophthalmia is also probably tuberculous-dicta nọt accepted without considerable reserve. 
Meller succeeded Ernst Fuchs at Vienna; and maintained the outstanding reputation for clinical work, research and teaçhing which that centre had deservedly earned. The professor and his assistants spoke English, and held post-graduate classes which were especially appreciated by students from the United States.

His fame brought honours to him, and he was an honorary member of the Academy of Science in Vienna. He was an

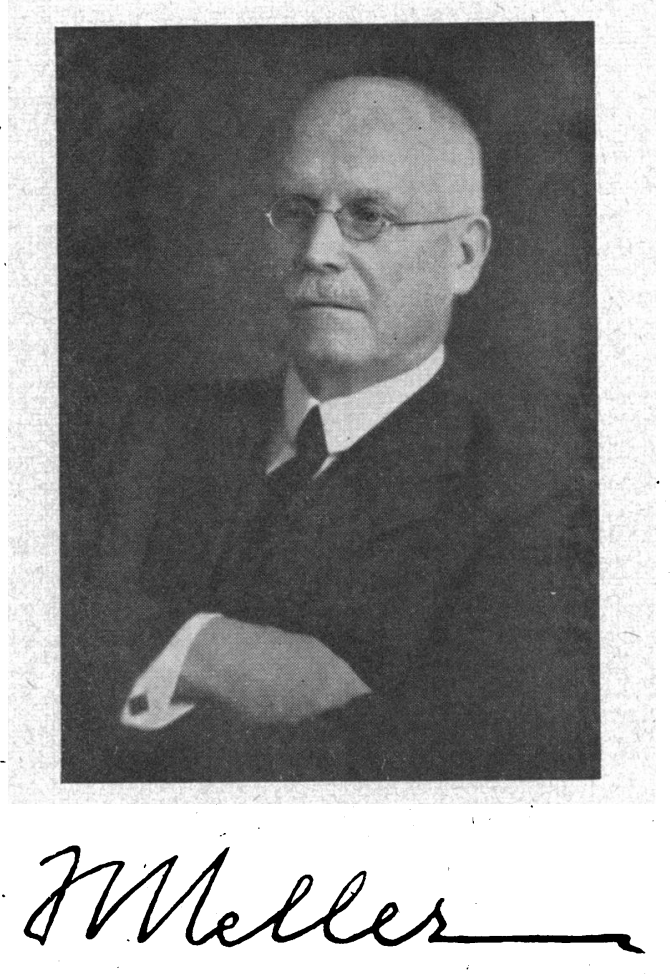

honorary member of the Ophthalmological Societies of the following countries: Hungary, Yugo-Slavia, Italy, Egypt, Brazil, Mexico and Greece. He was an honorary member of the Oxford Ophthalmological Congress and a recipient of the Doyne Medal. A list of his publications contains 124 items, mostly in the German literature between 1900 and 1941. To the English-speaking world he is best known by his book on ophthalmic surgery, of which the second edition was published in Philadelphia in 1912. It had an extensive sale for some years in this country. In Austria and Germany the " Augenärtzliche Eingriffe" ran to five editions.

F. A. J. 